- News \& Views •

\title{
Volcanoes and Climate: Sizing up the Impact of the Recent Hunga Tonga-Hunga Ha'apai Volcanic Eruption from a Historical Perspective ${ }^{*}$
}

\author{
Meng ZUO ${ }^{1}$, Tianjun ZHOU ${ }^{*}, 2$, Wenmin MAN ${ }^{1}$, Xiaolong CHEN ${ }^{1}$, Jian LIU ${ }^{3}$, Fei LIU ${ }^{4}$, and Chaochao GAO \\ ${ }^{1}$ State Key Laboratory of Numerical Modeling for Atmospheric Sciences and Geophysical Fluid Dynamics (LASG), \\ Institute of Atmospheric Physics, Chinese Academy of Sciences, Beijing 100029, China \\ ${ }^{2}$ University of Chinese Academy of Sciences, Beijing 100029, China \\ ${ }^{3}$ Key Laboratory for Virtual Geographic Environment, Ministry of Education, Jiangsu Provincial State Key Laboratory \\ Cultivation Base of Geographical Environment Evolution, School of Geography Science, \\ Nanjing Normal University, Nanjing 210023, China \\ ${ }^{4}$ School of Atmospheric Sciences Sun Yat-Sen University, Key Laboratory of Tropical Atmosphere-Ocean System Ministry \\ of Education, and Southern Marine Science and Engineering Guangdong Laboratory, Zhuhai 519082, China \\ ${ }^{5}$ College of Environmental and Resource Science, Zhejiang University, Hangzhou 310058, China
}

(Received 10 February 2022; revised 20 February 2022; accepted 23 February 2022)

\begin{abstract}
An undersea volcano at Hunga Tonga-Hunga Ha'apai (HTHH) near the South Pacific island nation of Tonga, erupted violently on 15 January 2022. Potential climate impact of the HTHH volcanic eruption is of great concern to the public; here, we intend to size up the impact of the HTHH eruption from a historical perspective. The influence of historical volcanic eruptions on the global climate are firstly reviewed, which are thought to have contributed to decreased surface temperature, increased stratospheric temperature, suppressed global water cycle, weakened monsoon circulation and $\mathrm{El}$ Niño-like sea surface temperature. Our understanding of the impacts of past volcanic eruptions on global-scale climate provides potential implication to evaluate the impact of the HTHH eruption. Based on historical simulations, we estimate that the current $\mathrm{HTHH}$ eruption with an intensity of $0.4 \mathrm{Tg} \mathrm{SO}_{2}$ injection will decrease the global mean surface temperature by only $0.004^{\circ} \mathrm{C}$ in the first year after eruption, which is within the amplitude of internal variability at the interannual time scale and thus not strong enough to have significant impacts on the global climate.
\end{abstract}

Key words: Hunga Tonga-Hunga Ha'apai volcanic eruption, global climate, surface temperature, monsoon, ENSO

Citation: Zuo, M., T. J. Zhou, W. M. Man, X. L. Chen, J. Liu, F. Liu, and C. C. Gao, 2022: Volcanoes and climate: Sizing up the impact of the recent Hunga Tonga-Hunga Ha'apai volcanic eruption from a historical perspective. Adv. Atmos. Sci., 39(12), 1986-1993, https://doi.org/10.1007/s00376-022-2034-1.

An undersea volcano at Hunga Tonga-Hunga Ha'apai (HTHH), which is located near the South Pacific island nation of Tonga, erupted violently on 15 January 2022, putting the entire Pacific rim on a tsunami watch. China's Fengyun-4B (FY4B) satellite operated by the China Meteorological Administration captured the eruption and is continuously monitoring the westward diffusion of volcanic ash clouds afterward (Fig. 1). Satellite measurements of the vertical profile of the aerosols show that the volcanic ash has reached an altitude of 30 kilometers, which is deep into the stratosphere.

The active HTHH volcano is located at $20.536^{\circ} \mathrm{S}, 175.382^{\circ} \mathrm{W}$. It has erupted many times since 1912 . An eruption in 2014 created a new island between the Hunga Tonga and Hunga Ha'apai Islands. After this latest eruption on 15 January 2022, most of the combined island was destroyed, and the ashfall and tsunami damaged all the islands of Tonga during the following days. According to the sulfur dioxide $\left(\mathrm{SO}_{2}\right)$ data covering most of the volcanic cloud, the total stratospheric $\mathrm{SO}_{2}$

\footnotetext{
※ This paper is a contribution to the special issue on Cloud-Aerosol-Radiation-Precipitation Interaction: Progress and Challenges.

* Corresponding author: Tianjun ZHOU

Email: zhoutj@lasg.iap.ac.cn
} 


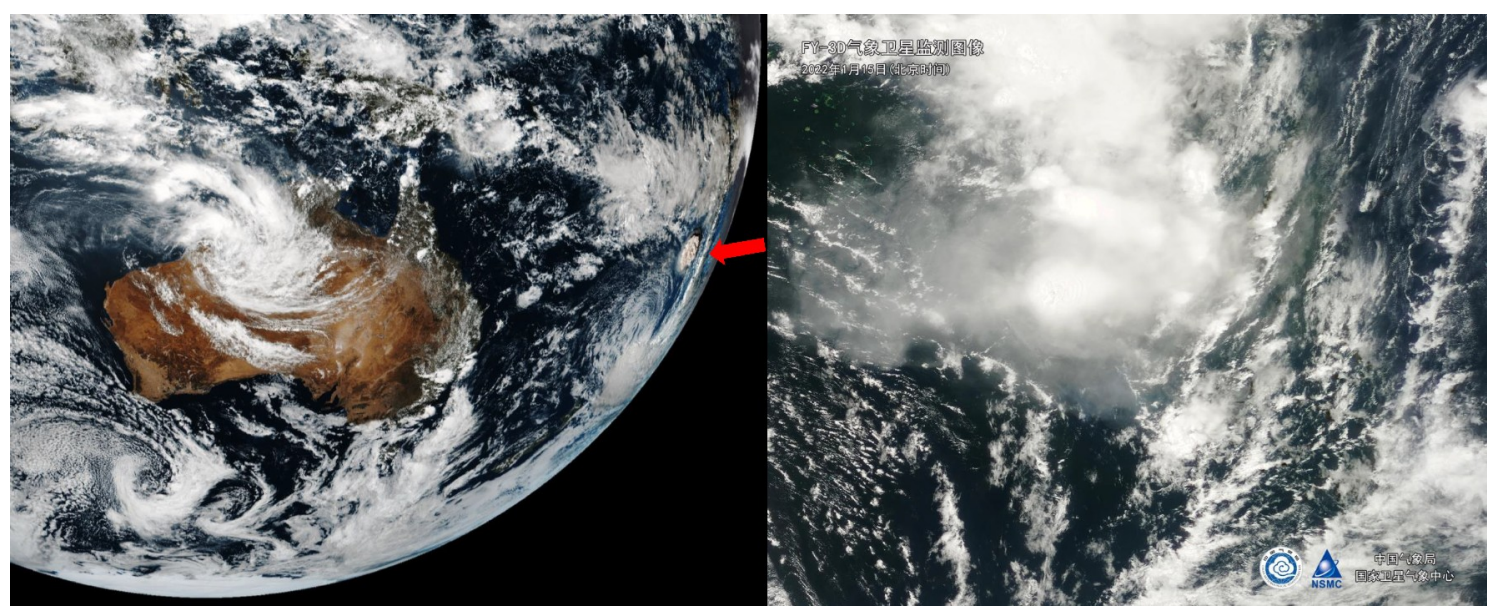

Fig. 1. The FY-4B satellite captured the eruption of the Hunga Tonga-Hunga Ha'apai (HTHH) volcano (left); monitoring the diffusion of volcanic ash clouds by the FY-4B satellite from 1545 to 2100 LST (Local Standard Time, LST=UTC+13 hours) on 15 January 2022 (right) (Provided by the National Satellite Meteorological Center of China).

mass was $~ 0.4 \mathrm{Tg}$ (terrogram) (from the TROPOMI satellite-based measurements of $\mathrm{SO}_{2}$ concentrations in the atmosphere, https://so2.gsfc.nasa.gov/tropomi_2019_now.html\#2022). Whether the eruption of the HTHH volcano will slow down the anthropogenic global warming tendency is of great concern to the public; here we expect to size up the impact of recent HTHH volcanic eruption from a historical perspective.

The $\mathrm{SO}_{2}$ injected into the stratosphere after volcanic eruptions is oxidized and converted to sulfate aerosols with an average residence time of 1-2 years, which would reduce the surface downward shortwave radiation and absorb the near infrared and outgoing longwave radiation, resulting in decreased surface temperature and increased stratospheric temperature (Robock, 2000). Changes in radiation further influence the climate system through dynamic processes, such as a suppressed global water cycle (Robock, 2000; Timmreck, 2012), anomalous winter Eurasian warming (Robock, 2000; Stenchikov et al., 2002), an El Niño-like sea surface temperature response (Zuo et al., 2018; Sun et al., 2019a), and weakened monsoon circulation (Man et al., 2012, 2014; Man and Zhou, 2014; Liu et al., 2016).

As the largest volcanic eruptions during the last 500 years, the eruption of Mount Tambora in Indonesia $\left(8.2^{\circ} \mathrm{S}\right.$, $118.0^{\circ}$ E) (Volcanic Explosivity Index, VEI=7, Newhall and Self, 1982) in April 1815 caused the so-called "Year Without a Summer" in 1816 over many parts of the world (Raible et al., 2016; Gao et al., 2017). A reduction in annual mean surface temperature over the tropics and Northern Hemisphere by $0.4^{\circ} \mathrm{C}-0.8^{\circ} \mathrm{C}$ has been estimated from proxy data (Wilson et al., 2007; D'Arrigo et al., 2009; Crowley et al., 2014). At the regional scale, Europe witnessed a more than $2^{\circ} \mathrm{C}$ colder climate (Raible et al., 2016). The annual mean surface temperature over Asia decreased by $\sim 0.7^{\circ} \mathrm{C}$, which was associated with increased droughts and famines (Gao et al., 2017). During the instrumental period, the eruption of Mount Pinatubo (VEI=6) in 1991 caused a decrease in global mean surface temperature by $\sim 0.2^{\circ} \mathrm{C}-0.3^{\circ} \mathrm{C}$ in the following 2 years (Stenchikov et al., 2002). However, the $\mathrm{SO}_{2}$ emissions of both eruptions, i.e., $20 \mathrm{Tg}$ for 1991 Pinatubo and 53-58 Tg for 1815 Tambora, were far greater than the $0.4 \mathrm{Tg}$ for the current emissions of the HTHH eruption (Bluth et al., 1997; Self et al., 2004).

The impact of a single volcanic eruption on the surface climate is generally limited to less than 5 years, and most evident in the following 1-2 years. The surface temperature generally returns to normal gradually as the volcanic aerosols dissipate; therefore a single volcanic eruption is not enough to change the long-term climate trend, unless there are clusters of volcanic eruptions that can persist through centuries as supposed for the Little Ice Age (Zhou et al., 2011a, b). Due to the limitation of observations, investigations on the impact of historical volcanism on climate rely heavily on proxy data and climate modeling. Analysis of past millennial climate simulations and comparison to reconstructions found global mean surface cooling during the following 2-3 years after major volcanic eruptions, with a stronger magnitude over land (Timmreck, 2012; Man et al., 2014; Paik and Min, 2017). In the Arctic region, however, cooling can even last for 16 years after strong volcanic eruptions due to sea ice feedbacks (Miller et al., 2012; Liu et al., 2020a, 2021). In addition to the thermal cooling effect related to atmospheric dimming, the dynamical effect also works in modulating regional climate. For example, over northern Eurasia and North America, winter warming is significant during the following two years after volcanic eruptions, as a result of a strengthened polar vortex related to an increased stratospheric meridional temperature gradient (Stenchikov et al., 2002; Zambri et al., 2017; Liu et al., 2020b; Xing et al., 2020).

In addition to temperature changes, global precipitation, which decreased significantly after major volcanic eruptions (Robock, 2000; Iles et al., 2013; Barnes et al., 2016), is associated with a suppressed water cycle, decreased surface runoff and fresh water resources (Grinsted et al., 2007; Iles and Hegerl, 2015; Liu et al., 2018a). The precipitation response to volcanic 


\section{(a) $\mathrm{NH}$ events}

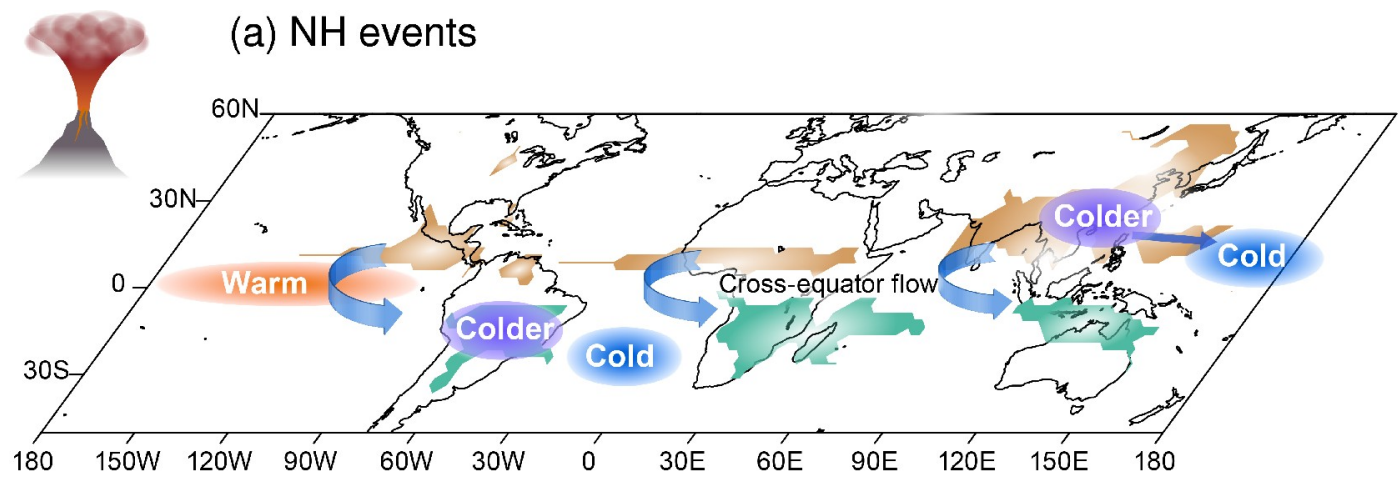

(b) TR events

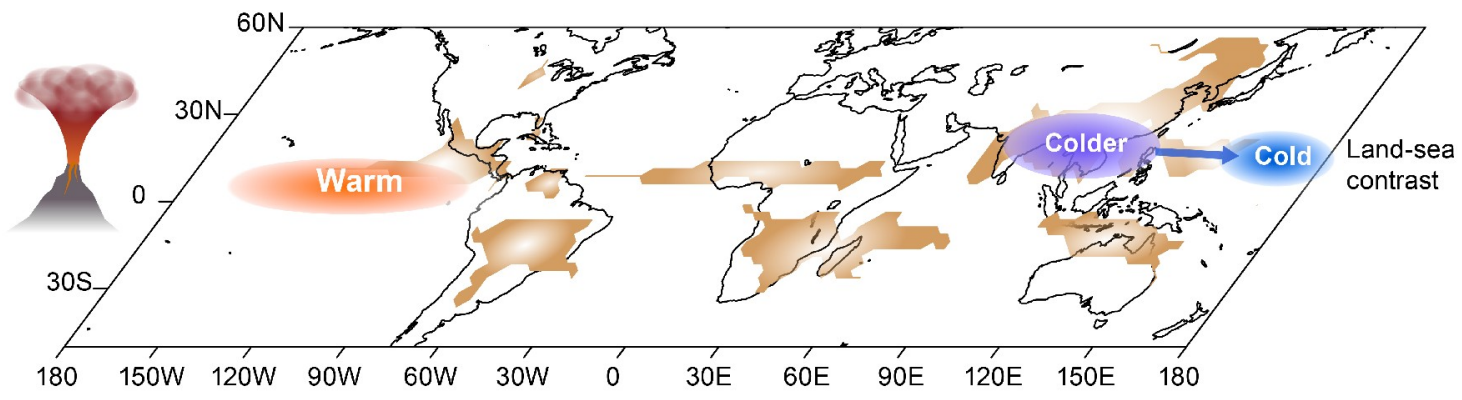

(c) $\mathrm{SH}$ events

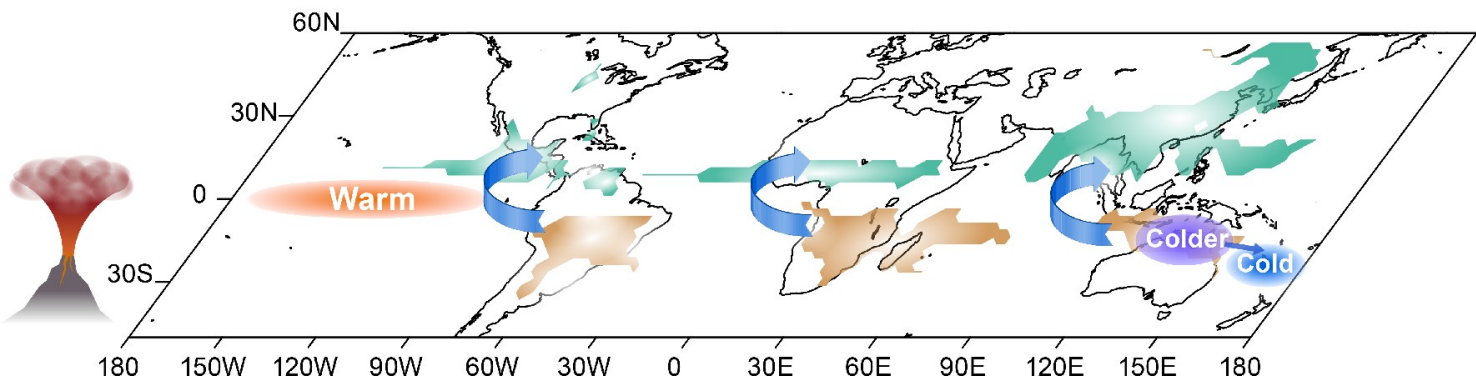

Fig. 2. Schematic diagrams of the precipitation responses to volcanic eruptions at different latitudes. Precipitation (shading) and low-level circulation (vectors) anomalies over monsoon regions in the first local summer following (a) Northern Hemisphere (NH), (b) tropical (TR), and (c) Southern Hemisphere (SH) volcanic eruptions. Increased and decreased precipitation are denoted by green and brown colors, respectively. The orange ellipses represent eastern Pacific warming. [Reprinted from (Zuo et al., 2019a)].

aerosol forcing is not uniform globally, with the precipitation over monsoon regions decreasing after tropical volcanic eruptions, whereas the arid regions become wetter (Figs. $2 \mathrm{~b}$ and $3 \mathrm{~b}$ ). Such spatial response patterns are affected by both thermodynamic processes related to specific humidity changes and dynamic processes related to atmospheric circulation changes (Iles et al., 2013; Zuo et al., 2019a, b). Over the densely populated East Asian monsoon regions, the decreased land-sea thermal contrast post-tropical volcanic eruptions weakened the monsoon circulation, resulting in decreased precipitation and increased drought events (Shen et al., 2007; Peng and Xu, 2009; Peng et al., 2010; Man et al., 2014; Chen et al., 2020; Zhuo et al., 2020; Gao et al., 2021). The response of extreme precipitation to volcanic eruptions is similar to the mean precipitation in sign, but with higher percentage changes (Paik and Min, 2018; Zuo et al., 2019a).

In comparison to tropical volcanic eruptions, high-latitude eruptions have characteristically different impacts on the global climate. Reconstructions and model simulations reveal that volcanic eruptions in one hemisphere can enhance (reduce) global monsoon precipitation in the other (same) hemisphere (Liu et al., 2016; Zuo et al., 2019a; Sun et al., 2020; Figs. 2a and c). Such a cross-hemisphere impact is also seen on regional scales (Haywood et al., 2013; Zhuo et al., 2014). Numerical modeling evidence suggests that the increased monsoon precipitation by the remote volcanic forcing is mainly caused by the enhanced cross-equator flow (Zuo et al., 2019a; Fig. 2). 

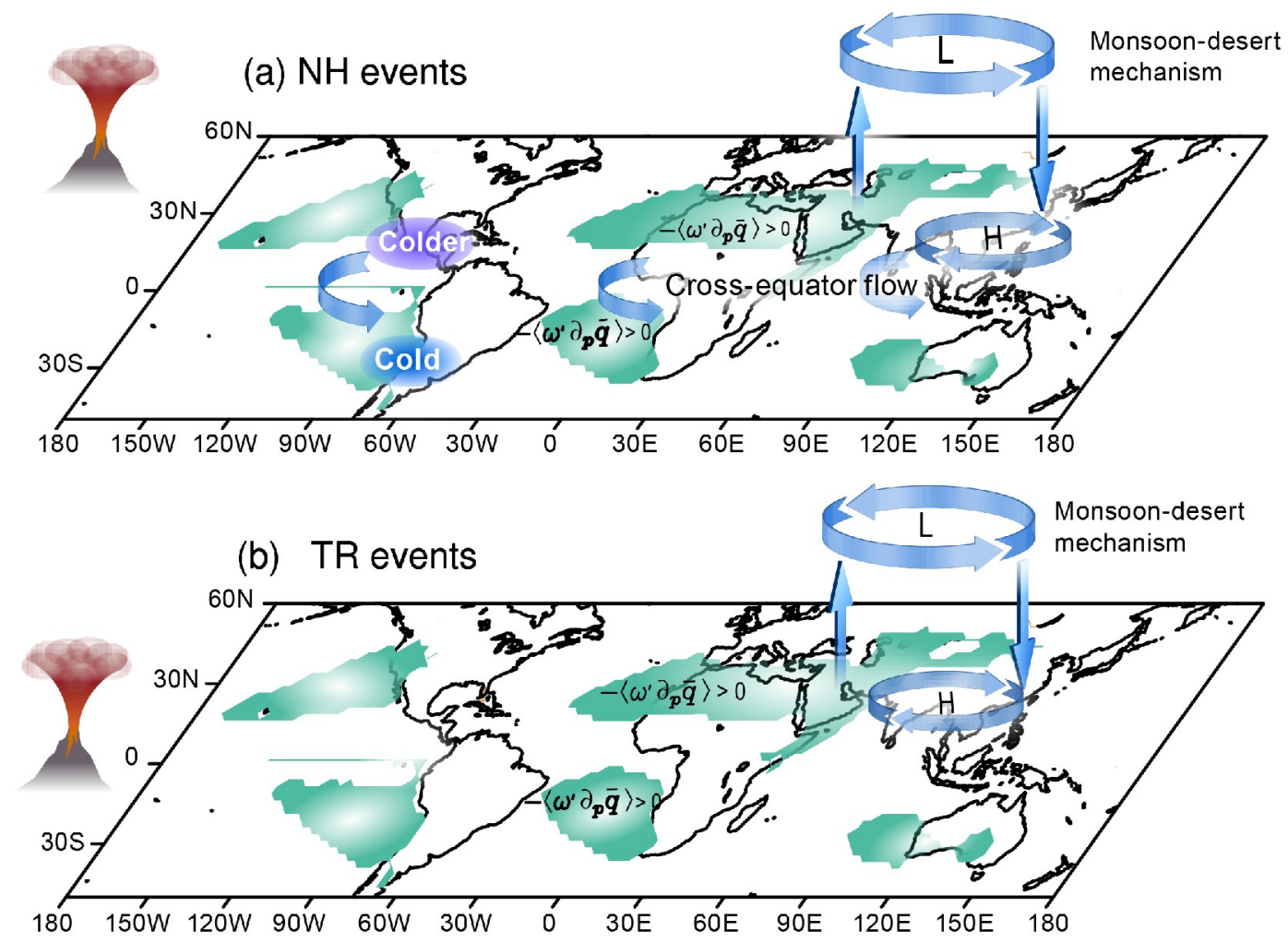

(c) $\mathrm{SH}$ events

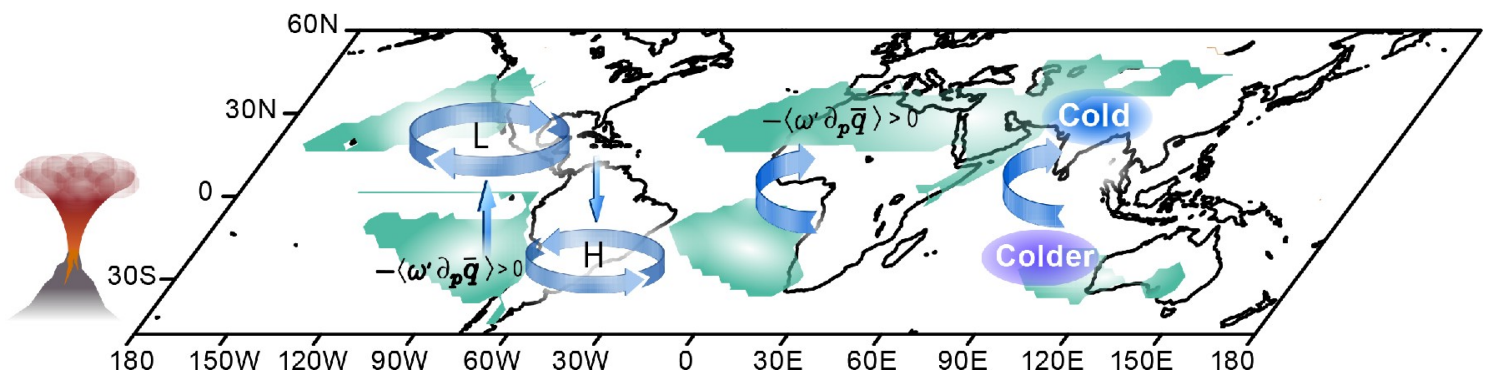

Fig. 3. Schematic diagrams of the precipitation responses to volcanic eruptions at different latitudes. Precipitation (shading, green color represents a positive response) and low-level circulation (vectors) anomalies over arid regions in the first local summer after (a) Northern Hemisphere (NH), (b) tropical (TR), and (c) Southern Hemisphere (SH) volcanic eruptions. The purple and blue ellipses denote the different magnitudes of surface cooling. [Reprinted from (Zuo et al., 2019b)].

Large eruptions of volcanoes can even alter the ocean state. El Niño-like warming over the tropical Pacific appears after large volcanic eruptions in both reconstructions and model simulations. The eastern Pacific favors a warm anomaly in the first winter after volcanic eruptions (Adams et al., 2003; Liu et al., 2018b; Zuo et al., 2018; Fig. 4) as a result of westerly anomalies over the western-to-central equatorial Pacific (Zuo et al., 2018; Chai et al., 2020), and turns to La Niña in the second year (Zuo et al., 2018; Sun et al., 2019b). The El Niño-Southern Oscillation (ENSO) responses to volcanic eruptions critically depend on the pre-eruption Pacific SST conditions (Liu et al., 2018c, 2020b; Predybaylo et al., 2020; Zuo et al., 2021). Under ENSO neutral and warm phase initial conditions, the Pacific favors an El Niño-like anomaly after volcanic eruptions, while La Niña-like sea surface temperature anomalies tend to occur following eruptions under ENSO cold phase initial conditions, which would further modulate monsoon precipitation changes (Zuo et al., 2021).

Climate projections are crucial to policy-making processes for climate change adaptation and mitigation activities (Zhou, 2021). However, episodic volcanic eruptions are not considered in the design of future climate scenarios due to their unpredictability. Numerical simulations reveal that the inclusion of volcanic eruptions in future projections would suppress the projected increase in monsoon precipitation and enhance climate variability (Bethke et al., 2017; Man et al., 2021).

A review of past volcanic eruptions is expected to help us predict the future impact. Then, how much would the HTHH 
(a) $\mathrm{NH}$ events

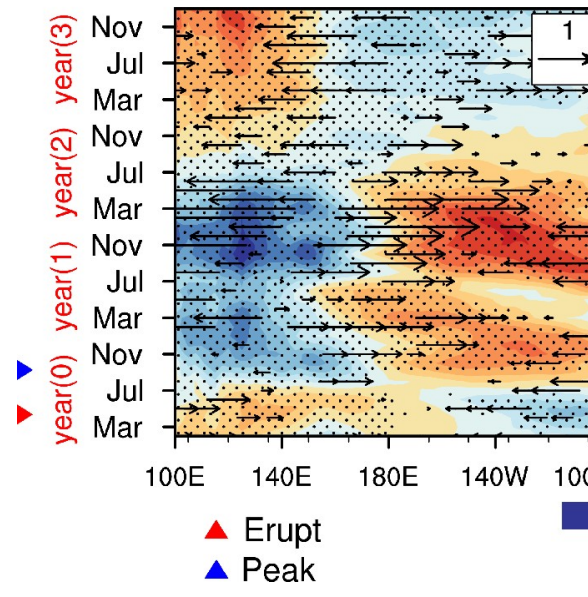

(b) TR events

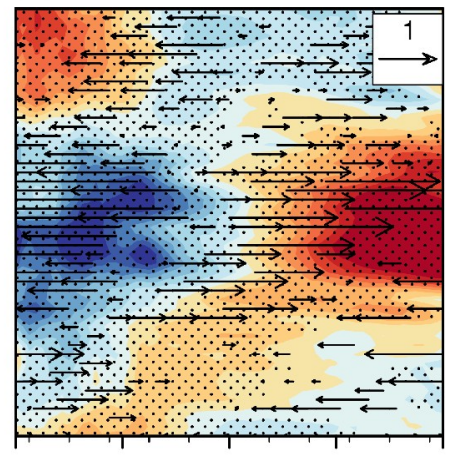

(c) SH events

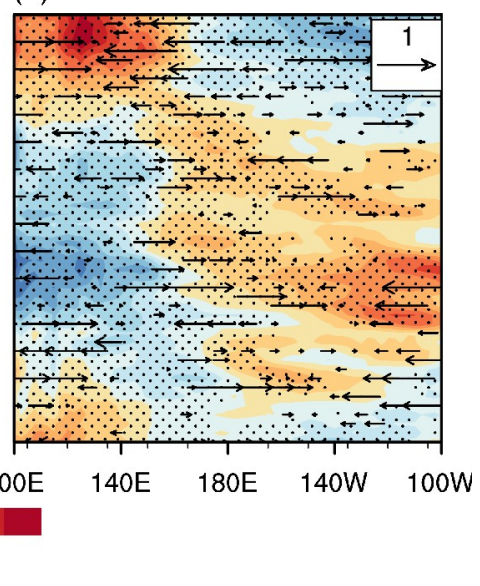

Fig. 4. Longitude-time sections of the sea surface temperature $\left({ }^{\circ} \mathrm{C}\right)$ and $850 \mathrm{hPa}$ zonal wind anomalies $\left(\mathrm{m} \mathrm{s}^{-1}\right)$ along the equatorial region $\left(10^{\circ} \mathrm{S}-10^{\circ} \mathrm{N}\right)$ from March of the eruption year to November of three years after (a) Northern Hemisphere (NH), (b) tropical (TR), and (c) Southern Hemisphere (SH) volcanic eruptions based on the CESM Last Millennium Ensemble simulations. [Reprinted from (Zuo et al., 2018)].

eruption affect the global climate? The impact of volcanoes erupting in the Southern Hemisphere $\left(20.5^{\circ} \mathrm{S}\right)$ would be different from those erupting in the Northern Hemisphere (such as El Chichón in 1982, $17.36^{\circ} \mathrm{N}$ ) and from those in the tropics (such as Agung in $1963,8.34^{\circ} \mathrm{S}$ ) due to the different spatial distributions of stratospheric sulfate aerosols (Zhuo et al., 2021). It is difficult to accurately estimate the impact of the HTHH eruption based on historical data since there are few similar southern volcanic eruptions among the observations; fortunately, climate model simulations driven by large southern volcanic eruptions in the last millennium provide a reference. Here, we first reveal the significant correlation between the intensity of 70 selected volcanic eruptions during the last millennium and the global mean surface temperature response in the first post eruption year based on CESM Last Millennium Ensemble (LME) simulations (Otto-Bliesner et al., 2016). A quasi-linear relationship is seen between the magnitude of surface cooling and the volcanic intensity (Fig. 5a). We further selected six large tropical eruptions for model simulations and scaled their surface temperature responses to the intensity of Mount Pinatubo in 1991 $\left(20 \mathrm{Tg}\right.$ injection of $\mathrm{SO}_{2}$ ) (Fig. $5 \mathrm{~b}$ ). We found that the scaled result based on model simulations were similar to the observations in terms of spatial distribution and global mean temperature responses (Fig. 5c), which adds fidelity to the scale method. To estimate the potential impact of the HTHH eruption on global surface temperature, we further linearly scaled the surface temperature anomaly after large southern volcanic eruptions according to the intensity of $0.4 \mathrm{Tg} \mathrm{SO}_{2}$ injection (Fig. 5d). The results show that the global mean surface temperature will decrease by only $0.004^{\circ} \mathrm{C}$ in the first year after the HTHH eruption. The cooling in the Southern Hemisphere is stronger than that in other parts of the world, with the strongest cooling of more than $0.01^{\circ} \mathrm{C}$ in parts of Australia and South America. The cooling over most parts of China is less than $0.01^{\circ} \mathrm{C}$. Hence, the current eruption of the HTHH volcano is not strong enough to overwhelm the global warming tendency or to have significant impacts on the global climate.

In addition, Zhang et al. (2022) recently estimated a reduction in global mean surface air temperature by approximately $0.0315^{\circ} \mathrm{C}-0.1118^{\circ} \mathrm{C}$ in the next $1-2$ years after the eruption of $\mathrm{HTHH}$ volcano. While the study provides a useful generalized framework that can quickly assess the impact of volcanic eruptions on global mean surface temperature based on a simplified radiation equilibrium model, the study may overestimate the temperature response to the HTHH eruption for the following reasons: (1) As a southern hemispheric volcano, the impact of the HTHH volcano would be mainly confined to the Southern Hemisphere and the tropics, with less impact on the Northern Hemisphere, leading to weaker global cooling than those of the Northern Hemisphere or tropical volcanoes. (2) They used the best estimate of the climate sensitivity parameter $\left[-0.862^{\circ} \mathrm{C}\left(\mathrm{W} \mathrm{m}^{-2}\right)^{-1}\right]$ from the Sixth Assessment Report of the Intergovernmental Panel on Climate Change (IPCC AR6), which is defined for $\mathrm{CO}_{2}$ forcing rather than solar forcing or volcanic forcing. The former changes the outgoing longwave radiation, whereas the latter changes incoming solar radiation. Evidence has shown that solar forcing has less efficacy in causing global temperature changes that have the same magnitude as $\mathrm{CO}_{2}$ forcing (Modak et al., 2016). This means that the climate sensitivity parameter for solar forcing should be smaller than that estimated for $\mathrm{CO}_{2}$ forcing [only $\sim 80 \%$ of the latter, $\left.0.67^{\circ} \mathrm{C}\left(\mathrm{W} \mathrm{m}^{-2}\right)^{-1}\right]$. More complex coupled model simulations driven by latitude-dependent sulfate aerosols are needed to quantitatively examine the effects of volcanic eruptions on climate.

Finally, how the HTHH eruption affects global and regional climate also depends on its future evolution. We should continue monitoring the activity of the HTHH volcano in the coming days/months/years. To date, no explosive eruptions have been detected at HTHH after the 15 January event. However, it may become active again in the future as it has erupted 
(a) Relation btw. ts ano and intensity

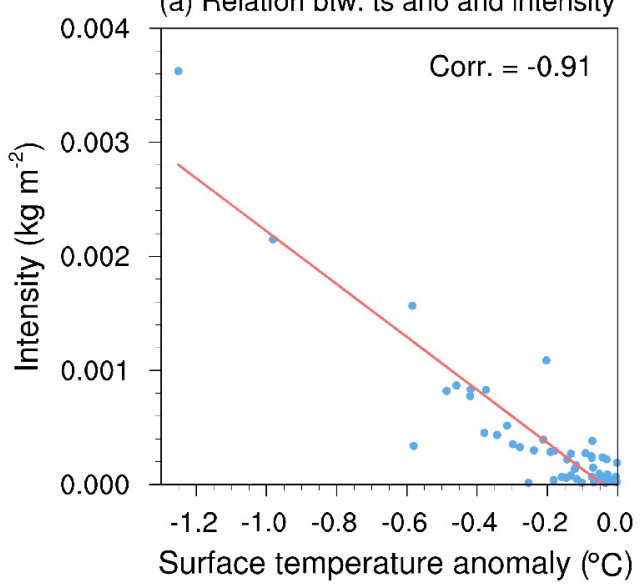

(c) Pinatubo (GISTEMP)

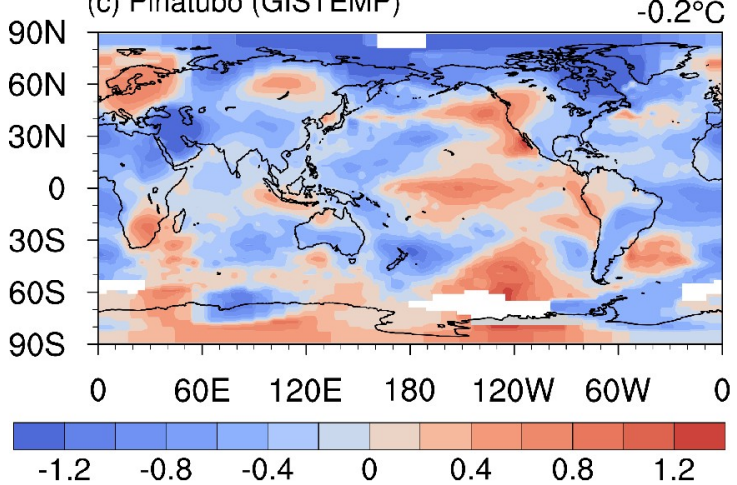

(b) Pinatubo (Scale from tropical eruptions) $-0.2^{\circ} \mathrm{C}$

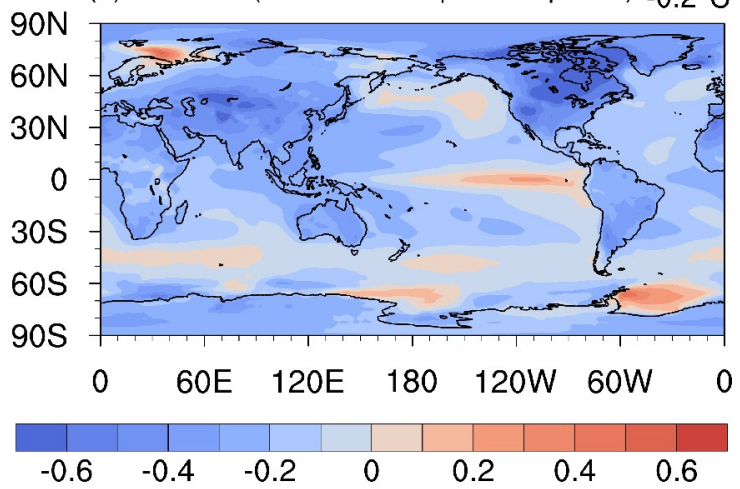

(d) Hunga Tonga (Scale from southern eruptions)

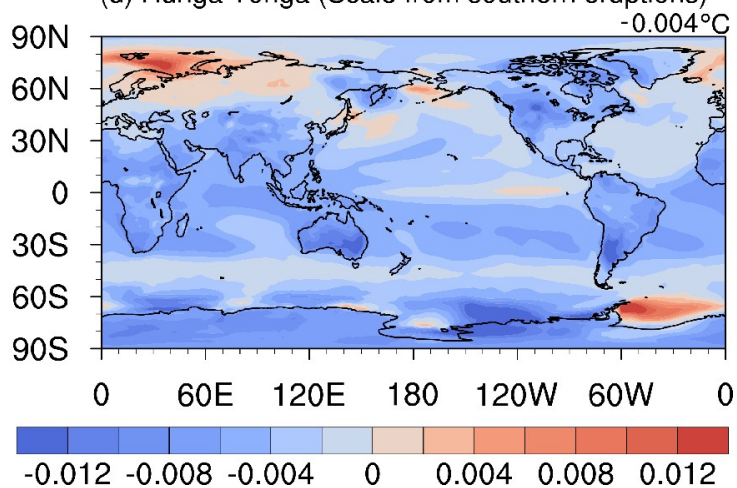

Fig. 5. Estimations of surface temperature changes in the first year after the HTHH eruption. (a) The relation between the intensity of volcanic eruptions and surface temperature anomalies in the first year after eruptions based on CESM Last Millennium Ensemble simulations. Blue dots indicate 70 volcanoes, and the red line is the linear regression. The correlation coefficient is shown at the top-right of the panel, which is significant at the 99\% confidence level. (b) Estimated surface temperature changes after Mount Pinatubo scaled from large tropical eruptions in CESM-LME; (c) Observed surface temperature changes after Mount Pinatubo based on GISTEMP. (d) Estimated surface temperature changes after the HTHH eruption scaled from large southern volcanic eruptions based on CESM-LME. The global mean response is shown at the top-right of the panel.

many times over the past 100 years. It could have a significant impact on the global climate if a HTHH volcano erupted again with greater amounts of $\mathrm{SO}_{2}$ injected into the stratosphere.

Acknowledgements. This work was jointly supported by the National Natural Science Foundation of China (Grant Nos. 41988101, and 42105047). We thank the National Satellite Meteorological Center of China for providing valuable images from the FY-4B satellite.

\section{REFERENCES}

Adams, J. B., M. E. Mann, and C. M. Ammann, 2003: Proxy evidence for an El Niño-like response to volcanic forcing. Nature, 426, 274-278, https://doi.org/10.1038/nature02101.

Barnes, E. A., S. Solomon, and L. M. Polvani, 2016: Robust wind and precipitation responses to the mount pinatubo eruption, as simulated in the CMIP5 models. J. Climate, 29, 4763-4778, https://doi.org/10.1175/JCLI-D-15-0658.1.

Bethke, I., S. Outten, O. H. Otterå, E. Hawkins, S. Wagner, M. Sigl, and P. Thorne, 2017: Potential volcanic impacts on future climate variability. Nature Climate Change, 7, 799-805, https://doi.org/10.1038/nclimate3394.

Bluth, G. J. S., W. I. Rose, I. E. Sprod, and A. J. Krueger, 1997: Stratospheric loading of sulfur from explosive volcanic eruptions. The Journal of Geology, 105, 671-684, https://doi.org/10.1086/515972.

Chai, J., F. Liu, C. Xing, B. Wang, C. C. Gao, J. Liu, and D. L. Chen, 2020: A robust equatorial Pacific westerly response to tropical volcanism in multiple models. Climate Dyn., 55, 3413-3429, https://doi.org/10.1007/s00382-020-05453-6.

Chen, K. F., and Coauthors, 2020: One drought and one volcanic eruption influenced the history of China: The late ming dynasty megadrought. Geophys. Res. Lett., 47, e2020GL088124, https://doi.org/10.1029/2020GL088124.

Crowley, T. J., S. P. Obrochta, and J. H. Liu, 2014: Recent global temperature "plateau" in the context of a new proxy reconstruction. Earth's Future, 2, 281-294, https://doi.org/10.1002/2013EF000216. 
D'Arrigo, R., R. Wilson, and A. Tudhope, 2009: The impact of volcanic forcing on tropical temperatures during the past four centuries. Nature Geoscience, 2, 51-56, https://doi.org/10.1038/ngeo393.

Gao, C. C., Y. J. Gao, Q. Zhang, and C. M. Shi, 2017: Climatic aftermath of the 1815 Tambora eruption in China. Journal of Meteorological Research, 31, 28-38, https://doi.org/10.1007/s13351-017-6091-9.

Gao, C.-C., L.-S. Yang, and F. Liu, 2021: Hydroclimatic anomalies in China during the post-Laki years and the role of concurring El Niño. Advances in Climate Change Research, 12, 187-198, https://doi.org/10.1016/j.accre.2021.03.006.

Grinsted, A., J. C. Moore, and S. Jevrejeva, 2007: Observational evidence for volcanic impact on sea level and the global water cycle. Proceedings of the National Academy of Sciences of the United States of America, 104, 19 730-19 734, https://doi.org/10.1073/pnas. 0705825104.

Haywood, J. M., A. Jones, N. Bellouin, and D. Stephenson, 2013: Asymmetric forcing from stratospheric aerosols impacts Sahelian rainfall. Nature Climate Change, 3, 660-665, https://doi.org/10.1038/nclimate1857.

Iles, C. E., and G. C. Hegerl, 2015: Systematic change in global patterns of streamflow following volcanic eruptions. Nature Geoscience, 8, 838-842, https://doi.org/10.1038/ngeo2545.

Iles, C. E., G. C. Hegerl, A. P. Schurer, and X. B. Zhang, 2013: The effect of volcanic eruptions on global precipitation. J. Geophys. Res., 118, 8770-8786, https://doi.org/10.1002/jgrd.50678.

Liu, B., B. Wang, J. Liu, D. L. Chen, L. Ning, M. Yan, W. Y. Sun, and K. F. Chen, 2020a: Global and polar region temperature change induced by single mega volcanic eruption based on community earth system model simulation. Geophys. Res. Lett., 47, e2020GL089416, https://doi.org/10.1029/2020GL089416.

Liu, B., C. Zhao, L. Zhu, and J. Liu, 2021: Seasonal changes in arctic cooling after single mega volcanic eruption. Frontiers in Earth Science, 9, 688250, https://doi.org/10.3389/feart.2021.688250.

Liu, F., J. Chai, B. Wang, J. Liu, X. Zhang, and Z. Y. Wang, 2016: Global monsoon precipitation responses to large volcanic eruptions. Scientific Reports, 6, 24331, https://doi.org/10.1038/srep24331.

Liu, F., T. L. Zhao, B. Wang, J. Liu, and W. B. Luo, 2018a: Different global precipitation responses to solar, volcanic, and greenhouse gas forcings. J. Geophys. Res., 123, 4060-4072, https://doi.org/10.1029/2017JD027391.

Liu, F., J. B. Li, B. Wang, J. Liu, T. Li, G. Huang, and Z. Y. Wang, 2018b: Divergent El Niño responses to volcanic eruptions at different latitudes over the past millennium. Climate Dyn., 50, 3799-3812, https://doi.org/10.1007/s00382-017-3846-z.

Liu, F., C. Xing, L. Y. Sun, B. Wang, D. L. Chen, and J. Liu, 2018c: How do Tropical, Northern Hemispheric, and Southern Hemispheric volcanic eruptions affect ENSO under different initial ocean conditions? Geophys. Res. Lett., 45, 13 041-13 049, https://doi.org/10. 1029/2018GL080315.

Liu, F., and Coauthors, 2020b: Could the recent taal volcano eruption trigger an El Niño and lead to eurasian warming. Adv. Atmos. Sci., 37, 663-670, https://doi.org/10.1007/s00376-020-2041-z.

Man, W. M., and T. J. Zhou, 2014: Response of the East Asian summer monsoon to large volcanic eruptions during the last millennium. Chinese Science Bulletin, 59, 4123-4129, https://doi.org/10.1007/s11434-014-0404-5.

Man, W. M., T. J. Zhou, and J. H. Jungclaus, 2012: Simulation of the East Asian summer monsoon during the last millennium with the MPI earth system model. J. Climate, 25, 7852-7866, https://doi.org/10.1175/JCLI-D-11-00462.1.

Man, W. M., T. J. Zhou, and J. H. Jungclaus, 2014: Effects of large volcanic eruptions on global summer climate and East Asian monsoon changes during the last millennium: Analysis of MPI-ESM simulations. J. Climate, 27, 7394-7409, https://doi.org/10.1175/JCLI-D13-00739.1.

Man, W. M., M. Zuo, T. J. Zhou, J. T. Fasullo, I. Bethke, X. L. Chen, L. W. Zou, and B. Wu, 2021: Potential influences of volcanic eruptions on future global land monsoon precipitation changes. Earth's Future, 9, e2020EF001803, https://doi.org/10.1029/2020EF001803.

Miller, G. H., and Coauthors, 2012: Abrupt onset of the Little Ice Age triggered by volcanism and sustained by sea-ice/ocean feedbacks. Geophys. Res. Lett., 39, L02708, https://doi.org/10.1029/2011GL050168.

Modak, A., G. Bala, L. Cao, and K. Caldeira, 2016: Why must a solar forcing be larger than a $\mathrm{CO}_{2}$ forcing to cause the same global mean surface temperature change. Environmental Research Letters, 11, 044013, https://doi.org/10.1088/1748-9326/11/4/044013.

Newhall, C. G., and S. Self, 1982: The volcanic explosivity index (VEI) an estimate of explosive magnitude for historical volcanism. $J$ Geophys. Res., 87, 1231-1238, https://doi.org/10.1029/JC087iC02p01231.

Otto-Bliesner, B. L., and Coauthors, 2016: Climate variability and change since $850 \mathrm{CE}$ : An ensemble approach with the community earth system model. Bull. Amer. Meteor. Soc., 97, 735-754, https://doi.org/10.1175/BAMS-D-14-00233.1.

Paik, S., and S.-K. Min, 2017: Climate responses to volcanic eruptions assessed from observations and CMIP5 multi-models. Climate Dyn., 48, 1017-1030, https://doi.org/10.1007/s00382-016-3125-4.

Paik, S., and S.-K. Min, 2018: Assessing the impact of volcanic eruptions on climate extremes using CMIP5 models. J. Climate, 31, 5333-5349, https://doi.org/10.1175/JCLI-D-17-0651.1.

Peng, Y. B., and Y. Xu, 2009: A modeling study on drought and flood events of the last 530 years in East China. Quaternary Sciences, 29, 1095-1103, https://doi.org/10.3969/j.issn.1001-7410.2009.06.11. (in Chinese with English abstract)

Peng, Y. B., C. M. Shen, W.-C. Wang, and Y. Xu, 2010: Response of summer precipitation over Eastern China to large volcanic eruptions. J. Climate, 23, 818-824, https://doi.org/10.1175/2009JCLI2950.1.

Predybaylo, E., G. Stenchikov, A. T. Wittenberg, and S. Osipov, 2020: El Niño/Southern oscillation response to low-latitude volcanic eruptions depends on ocean pre-conditions and eruption timing. Communications Earth \& Environment, 1, 12, https://doi.org/10. 1038/s43247-020-0013-y.

Raible, C. C., and Coauthors, 2016: Tambora 1815 as a test case for high impact volcanic eruptions: Earth system effects. Wiley Interdisciplinary Reviews: Climate Change, 7, 569-589, https://doi.org/10.1002/wcc.407.

Robock, A., 2000: Volcanic eruptions and climate. Rev. Geophys., 38, 191-219, https://doi.org/10.1029/1998RG000054. 
Self, S., R. Gertisser, T. Thordarson, M. R. Rampino, and J. A. Wolff, 2004: Magma volume, volatile emissions, and stratospheric aerosols from the 1815 eruption of Tambora. Geophys. Res. Lett., 31, L20608, https://doi.org/10.1029/2004GL020925.

Shen, C. M., W.-C. Wang, Z. X. Hao, and W. Gong, 2007: Exceptional drought events over eastern China during the last five centuries. Climatic Change, 85, 453-471, https://doi.org/10.1007/s10584-007-9283-y.

Stenchikov, G., A. Robock, V. Ramaswamy, M. D. Schwarzkopf, K. Hamilton, and S. Ramachandran, 2002: Arctic Oscillation response to the 1991 Mount Pinatubo eruption: Effects of volcanic aerosols and ozone depletion. J. Geophys. Res., 107, 4803, https: //doi.org/10.1029/2002JD002090.

Sun, W. Y., B. Wang, J. Liu, D. L. Chen, C. C. Gao, L. Ning, and L. Chen, 2019a: How Northern high-latitude volcanic eruptions in different seasons affect ENSO. J. Climate, 32, 3245-3262, https://doi.org/10.1175/JCLI-D-18-0290.1.

Sun, W. Y., J. Liu, B. Wang, D. L. Chen, F. Liu, Z. Y. Wang, L. Ning, and M. C. Chen, 2019b: A "La Niña-like" state occurring in the second year after large tropical volcanic eruptions during the past 1500 years. Climate Dyn., 52, 7495-7509, https://doi.org/10. 1007/s00382-018-4163-x.

Sun, W. Y., B. Wang, D. L. Chen, C. C. Gao, G. N. Lu, and J. Liu, 2020: Global monsoon response to tropical and Arctic stratospheric aerosol injection. Climate Dyn., 55, 2107-2121, https://doi.org/10.1007/s00382-020-05371-7.

Timmreck, C., 2012: Modeling the climatic effects of large explosive volcanic eruptions. Wiley Interdisciplinary Reviews: Climate Change, 3, 545-564, https://doi.org/10.1002/wcc.192.

Wilson, R., and Coauthors, 2007: A matter of divergence: Tracking recent warming at hemispheric scales using tree ring data. J. Geophys. Res., 112, D17103, https://doi.org/10.1029/2006JD008318.

Xing, C., F. Liu, B. Wang, D. L. Chen, J. Liu, and B. Liu, 2020: Boreal winter surface air temperature responses to large tropical volcanic eruptions in CMIP5 models. J. Climate, 33, 2407-2426, https://doi.org/10.1175/JCLI-D-19-0186.1.

Zambri, B., A. N. LeGrande, A. Robock, and J. Slawinska, 2017: Northern Hemisphere winter warming and summer monsoon reduction after volcanic eruptions over the last millennium. J. Geophys. Res., 122, 7971-7989, https://doi.org/10.1002/2017JD026728.

Zhang, H., F. Wang, J. Li, Y. H. Duan, C. W. Zhu, and J. Y. He, 2022: Potential impact of Tonga volcano eruption on global mean surface air temperature. Journal of Meteorological Research, 36, 1-5, https://doi.org/10.1007/s13351-022-2013-6.

Zhou, T. J., 2021: New physical science behind climate change: What does IPCC AR6 tell us. Innovation (N Y), 2, 100173, https://doi. org/10.1016/j.xinn.2021.100173.

Zhou, T. J., B. Li, W. M. Man, L. X. Zhang, and J. Zhang, 2011a: A comparison of the Medieval Warm Period, Little Ice Age and 20th century warming simulated by the FGOALS climate system model. Chinese Science Bulletin, 56, 3028-3041, https://doi.org/10. 1007/s11434-011-4641-6.

Zhou, X. J., P. Zhao, G. Liu, and T. J. Zhou, 2011b: Characteristics of decadal-centennial-scale changes in East Asian summer monsoon circulation and precipitation during the Medieval Warm Period and Little Ice Age and in the present day. Chinese Science Bulletin, 56, 3003-3011, https://doi.org/10.1007/s11434-011-4651-4.

Zhuo, Z., C. Gao, I. Kirchner, and U. Cubasch, 2020: Impact of volcanic aerosols on the hydrology of the Asian monsoon and westerliesdominated subregions: Comparison of proxy and multimodel ensemble means. J. Geophys. Res., 125, e2020JD032831, https://doi org/10.1029/2020JD032831.

Zhuo, Z. H., C. C. Gao, and Y. Q. Pan, 2014: Proxy evidence for China's monsoon precipitation response to volcanic aerosols over the past seven centuries. J. Geophys. Res., 119, 6638-6652, https://doi.org/10.1002/2013JD021061.

Zhuo, Z. H., I. Kirchner, S. Pfahl, and U. Cubasch, 2021: Climate impact of volcanic eruptions: The sensitivity to eruption season and latitude in MPI-ESM ensemble experiments. Atmospheric Chemistry and Physics, 21, 13 425-13 442, https://doi.org/10.5194/acp-21$13425-2021$.

Zuo, M., W. M. Man, T. J. Zhou, and Z. Guo, 2018: Different impacts of northern, tropical, and southern volcanic eruptions on the tropical pacific SST in the last millennium. J. Climate, 31, 6729-6744, https://doi.org/10.1175/JCLI-D-17-0571.1.

Zuo, M., T. J. Zhou, and W. M. Man, 2019a: Hydroclimate responses over global monsoon regions following volcanic eruptions at different latitudes. J. Climate, 32, 4367-4385, https://doi.org/10.1175/JCLI-D-18-0707.1.

Zuo, M., T. J. Zhou, and W. M. Man, 2019b: Wetter global arid regions driven by volcanic eruptions. J. Geophys. Res., 124, 13648-13662, https://doi.org/10.1029/2019JD031171.

Zuo, M., W. M. Man, and T. J. Zhou, 2021: Dependence of global monsoon response to volcanic eruptions on the background oceanic states. J. Climate, 34, 8273-8289, https://doi.org/10.1175/JCLI-D-20-0891.1. 